\title{
Characterization and Enzyme Engineering of a Hyperthermophilic Laccase Toward Improving Its Activity in Ionic Liquid
}

\author{
Joseph Craig Stevens ${ }^{1 *}$, David W. Rodgers ${ }^{2}$, Claire Dumon ${ }^{3}$ and Jian Shi ${ }^{1}$ \\ ${ }^{1}$ Department of Biosystems and Agricultural Engineering, University of Kentucky, Lexington, KY, United States, ${ }^{2}$ Department \\ of Molecular and Cellular Biochemistry and Center for Structural Biology, University of Kentucky, Lexington, KY, \\ United States, ${ }^{3}$ TBI, Université de Toulouse, CNRS, INRAE, INSA, Toulouse, France
}

\section{OPEN ACCESS}

Edited by:

Michael C. Jewett,

Northwestern University,

United States

Reviewed by:

Yuan Lu,

Tsinghua University, China

Sujit Jagtap

University of Illinois

at Urbana-Champaign, United States

*Correspondence:

Joseph Craig Stevens

jcst249@g.uky.edu

Specialty section:

This article was submitted to

Bioenergy and Biofuels,

a section of the journal

Frontiers in Energy Research

Received: 26 April 2020

Accepted: 23 June 2020

Published: 24 July 2020

Citation:

Stevens JC, Rodgers DW,

Dumon C and Shi J (2020)

Characterization and Enzyme

Engineering of a Hyperthermophilic Laccase Toward Improving Its Activity

in Ionic Liquid.

Front. Energy Res. 8:158. doi: 10.3389/fenrg.2020.00158
Ionic liquids (ILS) are organic salts molten at room temperature that can be used for a wide variety of applications. Many ILs, such as 1-ethyl-3-methylimidazolium acetate $\left(\left[\mathrm{C}_{2} \mathrm{C}_{1} \mathrm{Im}\right][\mathrm{OAc}]\right)$, have been shown to remove a significant fraction of the complex biopolymer lignin from biomass during pretreatment. Valorizing lignin via biological pathways (e.g., enzymes) holds promise but is limited by the low biocompatibility of many ILs used for pretreatment. The discovery of thermostable enzymes and the application of enzyme engineering techniques have yielded biocatalysts capable of withstanding high concentrations of ILS. Converting lignin from a waste product to value-added chemicals is vital to the success of future cellulosic biorefineries. To that end, we screened the activity of the lignolytic enzyme laccase from a hyperthermophilic bacterium (Thermus thermophilus) in aqueous $\left[\mathrm{C}_{2} \mathrm{C}_{1} \mathrm{Im}\right][\mathrm{OAc}]$. Despite the thermophilicity $\left(\mathrm{T}_{\text {opt }}>90^{\circ} \mathrm{C}\right)$ of this laccase, significant activity loss ( $\left.>50 \%\right)$ was observed in only $2 \%(\mathrm{w} / \mathrm{v})\left[\mathrm{C}_{2} \mathrm{C}_{1} \mathrm{Im}\right][\mathrm{OAc}]$. Kinetics studies show that the IL can bind to the free enzyme and the enzyme-substrate complex. Docking simulations suggest that the cation favors binding to a region close to the active site. We then used a rational design strategy to improve the activity of the laccase in $\left[\mathrm{C}_{2} \mathrm{C}_{1} \mathrm{Im}\right][\mathrm{OAc}]$. A total of 8 single amino acid mutations were made; however, there were no significant improvements in the activity of the mutants in $\left[\mathrm{C}_{2} \mathrm{C}_{1} \mathrm{Im}\right][\mathrm{OAc}]$ compared to the wild type. The results of this study shed light on the complex nature of enzyme-IL interactions and the challenges faced when designing a biological lignin valorization strategy.

Keywords: lignin, laccase, enzyme engineering, rational design, biocatalysis, ionic liquids

\section{INTRODUCTION}

Lignin is a complex biopolymer that makes up $\sim 30 \%$ of the terrestrial plant biomass on earth (Weng and Chapple, 2010; Doherty et al., 2011). It is made primarily of 3 phenylpropanoid subunits, syringyl (S), guaiacyl (G), and p-hydroxyphenyl (H) (Vanholme et al., 2010; Sette et al., 2011). These subunits are joined via complex networks of ether and carbon-carbon linkages with the $\beta$-aryl ether ( $\beta-O-4)$, phenylcoumaran $(\beta-5)$ and pinoresinol $(\beta-\beta)$ linkages being the most common (Boerjan et al., 2003; Zeng et al., 2013). Additionally, the ratio of subunits is not homogeneous across all sources of biomass (Suhas and Ribeiro Carrott, 2007). Due to this monomeric and structural heterogeneity, lignin is recalcitrant to biological and chemical 
depolymerization processes for production of aromatic compounds at high selectivity and yield. Lignin is currently generated as waste in large volumes in the paper and pulping industry and in cellulosic biofuel production (National Research Council et al., 2009; Tilman et al., 2009). Converting lignin to value-added products will not only reduce waste production, but will also add value to the paper and pulping industries and future cellulosic biorefineries (Ragauskas et al., 2014; Mottiar et al., 2016).

Although applications of lignin are limited in its polymeric form, the phenolic products derived from lignin can be used for production of fuels or as building blocks for chemicals used in the plastics, food, or pharmaceutical industries (Kleinert and Barth, 2008; Cotoruelo et al., 2011). Broadly speaking current methods used for converting lignin to value-added products can be divided into thermochemical, including pyrolysis, hydrogenolysis, and catalytic oxidation, and biological, including the use of lignolytic enzymes or microbes to break down lignin (Laskar et al., 2013; De Wild et al., 2014; Beckham et al., 2016). Biological methods utilize milder reaction conditions, with associated cost and safety advantages, and can potentially improve the yield and selectivity of lignin breakdown products due to the inherent efficiency of biocatalysts (Linger et al., 2014; Beckham et al., 2016). Several lignolytic pathways have been identified in biomassdegrading fungi and bacteria. These include the heme peroxidases (versatile, lignin, and manganese), laccases, and the recently discovered NAD or glutathione-dependent enzymes from the soil bacterium Sphingobium SYK-6 (Shi et al., 2012; Munk et al., 2015; Varmana et al., 2016). The application of these enzymes in an industrial setting has been limited by several factors, including the high cost of enzyme production, the poor solubility of lignin in a biocompatible solvent, and low selectivity of lignin-derived monomers by the biocatalyst (Bugg et al., 2011; Brown and Chang, 2014).

Many of the known lignin solvents, e.g., dimethyl sulfoxide (DMSO) or alkaline solutions, reduce or eliminate enzyme activity (Mozhaev et al., 1989; Klibanov, 2001). Furthermore, these solvents require the use of high temperatures for enhanced lignin solubilization (Park and Kazlauskas, 2003), which also eliminates enzyme activity. Therefore, a solvent that is both capable of solubilizing lignin and supporting enzyme activity is required for developing biological lignin valorization strategies. Ionic liquids (ILs) are molten, organic salts $\left(\mathrm{T}_{\mathrm{m}}<100^{\circ} \mathrm{C}\right)$ that can adopt a variety of properties by selecting the appropriate cation and anion (Brennecke and Maginn, 2001; Gutowski et al., 2003; Rogers and Seddon, 2003; Patel et al., 2014). Many alkylimidazolium ILs, particularly 1-ethyl-3-methylimidazolium acetate $\left(\left[\mathrm{C}_{2} \mathrm{C}_{1} \mathrm{Im}\right][\mathrm{OAc}]\right)$, have been extensively studied for use in biomass pretreatment at relatively low temperatures (Fort et al., 2007; Kilpeläinen et al., 2007; Verdia et al., 2014). Due to the high cost of alkylimidazolium ILs, recent efforts have focused on driving down the cost of ILs by using inexpensive, bio-derived cations (e.g., choline and ammonium) and anions (e.g., amino acids and carboxylic acids) and increasing the fraction of water during pretreatment (George et al., 2015; Gschwend et al., 2018). ILs are favored over other biomass pretreatment solvents due to their ability to reduce biomass recalcitrance, increase yield of fermentable sugars from enzymatic hydrolysis, and solubilize high fractions (5-20\%) of cellulose (Brandt et al., 2013; Shi et al., 2014; Bhatia et al., 2020).

Laccases are a member of the superfamily of multi-copper oxidases (E.C. 1.10.3.2). First discovered in the extract from the Japanese lacquer tree Toxicodendron vernicifluum, laccases have since been identified in fungi, bacteria, and archaea (Yoshida, 1883; Hullo et al., 2001; Kiiskinen et al., 2004; Miyazaki, 2005; An et al., 2015). Laccases differ from the other major lignolytic enzymes found in nature, the heme peroxidases, as they are copper containing enzymes that utilize molecular oxygen, as opposed to stronger oxidants, in their catalytic mechanism (Glenn et al., 1983; Piontek et al., 2002; Semba et al., 2015). The mild reaction conditions required for laccase activity have made them attractive targets for use in a variety of biotechnological applications, including lignin valorization (Singh Arora and Kumar Sharma, 2010). Additionally, laccases can oxidize non-phenolic lignin compounds when coupled with small molecule mediator compounds, like 2,2' azino-bis(3-ethylbenzothiazoline-6-sulfonic acid) (ABTS) or 1-hydroxybenzotriazole (HBT) (Gamelas et al., 2005; d'Acunzo et al., 2006; Rico et al., 2014). Recently, some ILs, including those investigated for use in biomass pretreatment have been found to be biocompatible with the activity of laccases. Several alkylimidazolium ILs were found to be biocompatible with the activity of a mesophilic fungal laccase from Trametes versicolor $(T v L)$ at different concentrations in water; over $80 \%$ of laccase activity remained in 50\% 1-ethyl-3-methylimidazolium ethylsulfate $\left(\left[\mathrm{C}_{2} \mathrm{C}_{1} \mathrm{Im}\right]\left[\mathrm{EtSO}_{4}\right]\right)$ (Domínguez et al., 2011), for example. However, this IL was shown to be the most biocompatible of the 4 alkylimidazolium ILs screened in the study. TvL activity was reduced by $50 \%$ in less than $40 \%$ 1-butyl-3-methylimidazolium chloride $\left(\left[\mathrm{C}_{4} \mathrm{C}_{1} \mathrm{Im}\right][\mathrm{Cl}]\right)$, 1-hexyl-3-methylimidazolium bromide $\left(\left[\mathrm{C}_{6} \mathrm{C}_{1} \mathrm{Im}\right][\mathrm{Cl}]\right)$, and 1decyl-3-methylimidazolium chloride $\left(\left[\mathrm{C}_{10} \mathrm{C}_{1}\right][\mathrm{Cl}]\right)$ (Domínguez et al., 2011). Additionally, we showed in a previous study that the same laccase loses $>50 \%$ activity in as little as $10 \%(\mathrm{w} / \mathrm{v})$ $\left[\mathrm{C}_{2} \mathrm{C}_{1} \mathrm{Im}\right][\mathrm{OAc}]$ and $1 \%(\mathrm{w} / \mathrm{v})[\mathrm{Ch}][\mathrm{Lys}]$, far below the IL concentrations required for effective biomass pretreatment (Stevens et al., 2019). If laccases are to be used as biocatalysts for lignin valorization, they must be able to withstand higher concentrations of ILs.

Recent strategies to improve enzyme activity and stability in ILs can be classified into three categories: chemical, physical, and biotechnological modifications. By reducing the ratio of positively charged to negatively charged surface residues via acetylation or succinylation, the activity and stability of enzymes can be improved in ILs (Erik and Kaar, 2013; Nordwald et al., 2014). Immobilization of laccase from Myceliophthora thermophila $(\mathrm{MtL})$ on glyoxyl-agarose beads improved enzyme stability in aqueous concentrations $(0-75 \%)$ of $\left[\mathrm{C}_{2} \mathrm{C}_{1} \mathrm{Im}\right]\left[\mathrm{EtSO}_{4}\right]$ (Fernández-Fernández et al., 2014). Single and multiple amino acid mutations have been used to improve the activity of laccases in alkylimidazolium ILs (Liu et al., 2013; Dabirmanesh et al., 2015; Wallraf et al., 2018). Recently, several thermotolerant organisms have been found to produce laccases or laccase-like enzymes. Due to the ability of these organisms to survive 
in conditions of extreme temperature, $\mathrm{pH}$, and salinity they prove to be useful sources of biocatalysts for industrial applications such as lignin valorization in aqueous ILs (Datta et al., 2010). Bacillus subtilis produces a laccase-like enzyme $\left(\mathrm{T}_{\text {opt }}>70^{\circ} \mathrm{C}\right)$ that is capable of oxidizing canonical laccase substrates such as syringaldazine and ABTS in the presence of several alkylimidazolium chloride ILs (Hullo et al., 2001; Dabirmanesh et al., 2015). The laccase produced by Thermus thermophilus $\left(\mathrm{T}_{\mathrm{opt}}>90^{\circ} \mathrm{C}\right)$, is the most thermotolerant laccase identified to date (Miyazaki, 2005). However, there has been no work to characterize the behavior of the T. thermophilus laccase in ILs in order to overcome the problem of laccase inhibition by alkylimidazolium ILs.

A primary screening with 3 ILs, diethylamine hydrogen sulfate $\left([\mathrm{DEA}]\left[\mathrm{HSO}_{4}\right]\right), \quad[\mathrm{Ch}][\mathrm{Lys}]$, and $\left[\mathrm{C}_{2} \mathrm{C}_{1} \mathrm{Im}\right][\mathrm{OAc}]$, revealed technical issues while measuring ABTS oxidation in $[\mathrm{DEA}]\left[\mathrm{HSO}_{4}\right]$ and [Ch][Lys] at high temperatures. Therefore, in this study we sought to characterize the interactions between the IL $\left[\mathrm{C}_{2} \mathrm{C}_{1} \mathrm{Im}\right][\mathrm{OAc}]$ and the laccase produced by $T$. thermophilus $(T t L)$. To do this, we first screened the biocompatibility of $\left[\mathrm{C}_{2} \mathrm{C}_{1} \mathrm{Im}\right][\mathrm{OAc}]$ with recombinantly produced $T t L$. We then used enzyme kinetics and docking simulations to better understand how $\left[\mathrm{C}_{2} \mathrm{C}_{1} \mathrm{Im}\right][\mathrm{OAc}]$ interacts with $T t L$. Finally, we used a rational design approach to make a series of single amino acid mutations in an effort to improve the activity of $T t L$ in $\left[\mathrm{C}_{2} \mathrm{C}_{1} \mathrm{Im}\right][\mathrm{OAc}]$. This study expands our understanding of the effects ILs can have on laccases and highlights some of the challenges faced when designing a biological lignin valorization strategy.

\section{MATERIALS AND METHODS}

\section{Materials}

2,2'-azino-bis(3-ethylbenzothiazoline-6-sulfonic acid) tablets were purchased from Thermo Fisher and the IL $\left[\mathrm{C}_{2} \mathrm{C}_{1} \mathrm{Im}\right][\mathrm{OAc}]$ was purchased from MilliporeSigma. The TtL sequence was codon optimized for Escherichia coli expression and inserted into pET32a(+) vector at $\mathrm{NcoI}$ and BamHI sites by GenScript (Piscataway, NJ, United States) to make the pET32aTtL expression plasmid. Mutant primers were purchased from Eurogentec (Seraing, Belgium). The PfuUltra HighFidelity DNA Polymerase, buffer, and dNTP mixture were purchased from Agilent.

\section{Expression of T. thermophilus Laccase}

The T. thermophilus laccase sequence (accession number I7AL37) was codon optimized for E. coli (Supplementary Figure S3). E. coli Rosetta (DE3) cells transformed with pET32aTtL were cultured in $1 \mathrm{~L} \mathrm{LB}$ broth containing ampicillin $(50 \mu \mathrm{g} / \mathrm{mL})$ and chloramphenicol $(34 \mu \mathrm{g} / \mathrm{mL})$ with shaking at $37^{\circ} \mathrm{C}$ until the optical density at $600 \mathrm{~nm}$ reached 0.5 . The laccase expression was induced by adding $1 \mathrm{mM}$ isopropyl $\beta$-D-1-thiogalactopyranoside (IPTG) and the culture was transferred to a $16^{\circ} \mathrm{C}$ shaker incubator overnight. Cells were collected by centrifugation and resuspended in $40 \mathrm{~mL}$ of lysis buffer $\left(50 \mathrm{mM} \mathrm{NaH}_{2} \mathrm{PO}_{4}, 300 \mathrm{mM}\right.$ $\mathrm{NaCl}, \mathrm{pH} 8.0$ ) and stored at $-20^{\circ} \mathrm{C}$ until purification.

\section{Purification and Copper-Induced Laccase Folding}

The frozen cells were thawed and subsequently sonicated on ice. The cell debris was removed by centrifugation at $15,000 \mathrm{rpm}$ for $50 \mathrm{~min}$ at $8^{\circ} \mathrm{C}$. The supernatant was heated for $1 \mathrm{~h}$ at $60^{\circ} \mathrm{C}$ to precipitate any heat sensitive protein, centrifuged for $30 \mathrm{~min}$ at $15,000 \mathrm{rpm}$, then filtered and loaded onto a column with $2.5 \mathrm{~mL}$ cobalt resin equilibrated with lysis buffer. The bound protein was washed with $15 \mathrm{~mL}$ lysis buffer followed by $5 \mathrm{~mL}$ wash buffer (50 $\mathrm{mM} \mathrm{NaH}_{2} \mathrm{PO}_{4}, 300 \mathrm{mM} \mathrm{NaCl}, 20 \mathrm{mM}$ imidazole, $\mathrm{pH}$ 8.0) to remove any protein bound to the column by non-specific binding. Finally, the protein was eluted with $5 \mathrm{~mL}$ elution buffer (50 $\mathrm{mM} \mathrm{NaH}_{2} \mathrm{PO}_{4}, 300 \mathrm{mM} \mathrm{NaCl}, 50 \mathrm{mM}$ imidazole, $\mathrm{pH}$ 8.0).

After purification, the native, copper-containing enzyme was produced according to a previously used protocol (Liu et al., 2011). The eluted protein was dialyzed twice against $1 \mathrm{~L}$ of a copper containing buffer $(20 \mathrm{mM}$ sodium acetate, $0.1 \mathrm{mM}$ $\mathrm{CuSO}_{4}, \mathrm{pH}$ 6.0) for $12 \mathrm{~h}$ at $4^{\circ} \mathrm{C}$. The protein was then dialyzed twice against $1 \mathrm{~L}$ of a copper-free buffer $(20 \mathrm{mM}$ sodium acetate, $\mathrm{pH} 4.5)$ for $12 \mathrm{~h}$ at $4^{\circ} \mathrm{C}$ to remove any remaining copper from the first dialysis step. Precipitate was removed by centrifugation at $15,000 \mathrm{rpm}$ for $20 \mathrm{~min}$ at $4^{\circ} \mathrm{C}$. The final protein concentration was determined by measuring the absorbance at $280 \mathrm{~nm}$ and using the molar absorption coefficient $\varepsilon_{280}=46,065 \mathrm{M}^{-1} \mathrm{~cm}^{-1}$.

\section{Biocompatibility Screening}

The biocompatibility of $\left[\mathrm{C}_{2} \mathrm{C}_{1} \mathrm{Im}\right][\mathrm{OAc}]$ in aqueous solution (approximately $1-10 \% \mathrm{w} / \mathrm{v}$ ), was screened with recombinant $T t L$. To reduce the effect of $\mathrm{pH}$, the IL solution was adjusted to $\mathrm{pH}$ 4.5 using $1 \mathrm{M}$ hydrochloric acid prior to testing. Activity was screened with $20 \mathrm{mM}$ sodium acetate buffer ( $\mathrm{pH} 4.5), 0.1 \mathrm{mM}$ $\mathrm{CuSO}_{4}$, IL $(0,1,2,3,4$, or $10 \% \mathrm{w} / \mathrm{v})$ and $2 \mathrm{mM}$ ABTS in quartz cuvettes with a $1 \mathrm{~cm}$ path length. Absorbance readings were taken continuously for $10 \mathrm{~min}$ at $61.5^{\circ} \mathrm{C}$. Oxidation of ABTS in buffer and AILs without laccase were measured as blanks. The relative activity of $T t L$ in ILs relative to buffer was calculated using equation 1.

$$
\text { Relative activity }=\frac{\text { Initial Velocity in IL }}{\text { Initial Velocity in buffer }}
$$

\section{Inhibition Kinetics}

Michaelis-Menten curves were generated for IL concentrations $(0,1,2,3$, and $4 \% \mathrm{w} / \mathrm{v})$ by varying the concentration of ABTS $(0.75-2.00 \mathrm{mM})$ and measuring initial velocities. ABTS oxidation was measured using the same method as described in the biocompatibility screening. The oxidized ABTS was quantified by measuring the absorbance at $420 \mathrm{~nm}$ and using the absorbance extinction coefficient $\varepsilon_{420}=36,000 \mathrm{M}^{-1} \mathrm{~cm}^{-1}$ (Liu et al., 2011). An activity unit was defined as $1 \mu \mathrm{mol}$ ABTS oxidized in $1 \mathrm{~min}$ ( $\mu \mathrm{mol} \mathrm{ABTS} / \mathrm{min})$. Initial velocity $(\mathrm{V})$ as a function of ABTS concentration ([S]) was fit to the Michaelis-Menten curve, shown in equation 2.

$$
V=\frac{V_{\max } *[S]}{K_{m}+[S]}
$$


The kinetic coefficients were calculated by plotting equation 2 in Sigma Plot and calculating $K_{m}$ and $V_{\max }$ using the ligand binding curve fitting algorithm.

\section{Docking Simulations}

The 3D structures and PDB files of the ligands were prepared in YASARA Structure (YASARA Biosciences GmbH, Vienna, Austria) using the SMILES strings obtained from PubChem. The PDBQT files of the ligands and TtL (PDBID: 2XU9) were prepared with AutoDock (version 4.2.6, MGLTools, La Jolla, CA, United States). Charges for the coppers were added by manually editing the TtL PDBQT file. AutoGrid parameters were as follows: space value of $0.375 \AA$, $(x, y, z)$ grid centered at $(-28.148,-27.636,14.016)$, and grid size of 126 in all directions. AutoDock parameters were as follows: Lamarckian GA, 1,000 genetic algorithm runs, and 25,000,000 max eval size. $\left[\mathrm{C}_{2} \mathrm{C}_{1} \mathrm{Im}\right]^{+}$ and $[\mathrm{OAc}]^{-}$were docked separately to both unbound $T t L$ and TtL with ABTS bound to the active site. The structure of $T t L$ with ABTS in the active site was prepared in PyMol by aligning $T t L$ with $B$. subtilis $\operatorname{Cot}$ A containing ABTS in the active site (PDBID: 1OF0).

\section{Site-Directed Mutagenesis of TtL}

Primer design and site-directed mutagenesis of $T t L$ was carried out using the QuikChange Site-Directed Mutagenesis Kit from Stratagene (La Jolla, CA, United States). Supplementary Table S1 lists the primers used in this study. The WT $T t L$ plasmid (pET32aTtL) was used as the template for all PCR reactions. The PCR reaction mixture $(50 \mathrm{uL})$ contained $5 \mathrm{ng}$ of DNA template, $125 \mathrm{ng}$ each of forward and reverse primers, $1 \mathrm{uL}$ dNTP mix, and $2.5 \mathrm{U}$ of polymerase. Reactions were conducted using the following sequence heated for $30 \mathrm{~s}$ at $95^{\circ} \mathrm{C}$ followed by 16 cycles of heating $\left(95^{\circ} \mathrm{C}, 30 \mathrm{sec}\right)$, annealing $\left(55^{\circ} \mathrm{C}, 1 \mathrm{~min}\right)$, and elongation $\left(68^{\circ} \mathrm{C}, 7.3 \mathrm{~min}\right)$. Following PCR, $D p n$ I restriction enzyme was added to digest the methylated template plasmid. Plasmid sequences were verified by Eurofins Genomics (Ebersberg, Germany). Expression, purification, and biocompatibility screening of TtL mutants were carried out using the previously described protocols in sections "Purification and Copper-Induced Laccase Folding" and "Biocompatibility Screening."

\section{RESULTS}

\section{WT TtL Biocompatibility Screening}

To determine the biocompatibility of $\left[\mathrm{C}_{2} \mathrm{C}_{1} \mathrm{Im}\right][\mathrm{OAc}]$, we screened the activity of $T t L$ in a range of IL concentrations in water. Figure $1 \mathbf{A}$ shows the activity of $T t L$ in different concentrations of $\left[\mathrm{C}_{2} \mathrm{C}_{1} \mathrm{Im}\right][\mathrm{OAc}]$ relative to the activity in buffer. A $50 \%$ reduction of $T t L$ initial velocity in buffer was seen in $2 \% \quad\left[\mathrm{C}_{2} \mathrm{C}_{1} \mathrm{Im}\right][\mathrm{OAc}]$, in contrast with recent studies of thermophilic enzymes in $\left[\mathrm{C}_{2} \mathrm{C}_{1} \mathrm{Im}\right][\mathrm{OAc}]$. A thermophilic cellulase $\left(\mathrm{T}_{\mathrm{opt}}=80^{\circ} \mathrm{C}\right)$ retained $40 \%$ initial activity in $20 \%\left[\mathrm{C}_{2} \mathrm{C}_{1} \mathrm{Im}\right][\mathrm{OAc}]$, while a hyperthermophilic cellulase $\left(\mathrm{T}_{\mathrm{opt}}>95^{\circ} \mathrm{C}\right)$ retained $90 \%$ initial activity in $20 \%\left[\mathrm{C}_{2} \mathrm{C}_{1} \mathrm{Im}\right][\mathrm{OAc}]$ (Datta et al., 2010). The range of
IL concentrations tested is relevant to previous studies investigating the effect of water on biomass pretreatment with ILs. When studying the role of water during pretreatment with $\left[\mathrm{C}_{2} \mathrm{C}_{1} \operatorname{Im}\right][\mathrm{OAc}]$, it was found that pretreatment efficacy is reduced when more than $50 \%$ water is present (Shi et al., 2014).

There are several factors that mediate the IL's effect on enzyme activity. In the case of alkylimidazolium ILs, the ability of the anion to disrupt the water shell around the protein (chaotropicity) and the alkyl chain length of the cation are thought to be largely responsible for the IL biocompatibility. The activity of $T v L$ was relatively unaffected by $50 \% 1$ ethyl-3-methylimidazolium ethyl sulfate $\left(\left[\mathrm{C}_{2} \mathrm{C}_{1} \mathrm{Im}\right]\left[\mathrm{EtSO}_{4}\right]\right)$, but was severely inhibited in ILs with longer alkyl chain length cations $\left(\left[\mathrm{C}_{4} \mathrm{C}_{1} \mathrm{Im}\right]^{+},\left[\mathrm{C}_{6} \mathrm{C}_{1} \mathrm{Im}\right]^{+}\right.$, and $\left.\left[\mathrm{C}_{10} \mathrm{C}_{1} \mathrm{Im}\right]^{+}\right)$and more chaotropic anions $\left(\mathrm{Cl}^{-}\right.$and $\left.\mathrm{Br}^{-}\right)$(Domínguez et al., 2011). An increase in the alkyl chain length of the alkylimidazolium chloride $\left(\left[\mathrm{C}_{\mathrm{n}} \mathrm{C}_{1} \mathrm{Im}\right][\mathrm{Cl}]\right)$ ILs $\left(\mathrm{C}_{2}->\mathrm{C}_{4}->\mathrm{C}_{6}\right)$ decreased the activity of $M t L$, followed by a greater decrease in activity when the alkyl chain length was further increased $\left(\mathrm{C}_{6}->\mathrm{C}_{10}\right)$ (Sun et al., 2017). Therefore, the short alkyl chain length $\left[\mathrm{C}_{2} \mathrm{C}_{1} \mathrm{Im}\right]^{+}$cation does not play a significant role in TtL inhibition. Rather, it is the chaotropic $[\mathrm{OAc}]^{-}$anion that causes the inhibition in low IL concentrations.

\section{Enzyme Kinetics}

To further understand the interaction between $\left[\mathrm{C}_{2} \mathrm{C}_{1} \mathrm{Im}\right][\mathrm{OAc}]$ and $T t L$, we carried out a more in depth investigated of enzyme kinetics using ABTS as a substrate (Figure 1B). With increasing concentrations of $\left[\mathrm{C}_{2} \mathrm{C}_{1} \mathrm{Im}\right][\mathrm{OAc}], \mathrm{K}_{\mathrm{m}}$ increased while the $\mathrm{k}_{\mathrm{cat}}$ decreased (Table 1 ). This suggests that $\left[\mathrm{C}_{2} \mathrm{C}_{1} \mathrm{Im}\right][\mathrm{OAc}]$ is a mixed competitive and non-competitive inhibitor of TtL. Such behavior could be the result of $\left[\mathrm{C}_{2} \mathrm{C}_{1} \mathrm{Im}\right][\mathrm{OAc}]$ interaction remote from the active site that decreases both substrate binding and catalysis, or the IL could be binding both at the active site and a remote location. As indicated in Table 1, $\mathrm{k}_{\text {cat }}$ was lowered from $0.42 \mathrm{~s}^{-1}$ in $0 \%\left[\mathrm{C}_{2} \mathrm{C}_{1} \mathrm{Im}\right][\mathrm{OAc}]$ to $0.29 \mathrm{~s}^{-1}$ in $1 \%\left[\mathrm{C}_{2} \mathrm{C}_{1} \mathrm{Im}\right][\mathrm{OAc}]$. However, a smaller reduction in kcat was observed between $1 \%$ $\left[\mathrm{C}_{2} \mathrm{C}_{1} \mathrm{Im}\right][\mathrm{OAc}]\left(0.29 \mathrm{~s}^{-1}\right)$ and $4 \%\left[\mathrm{C}_{2} \mathrm{C}_{1} \mathrm{Im}\right][\mathrm{OAc}]\left(0.20 \mathrm{~s}^{-1}\right)$. In contrast, $\mathrm{K}_{\mathrm{m}}$ steadily increased between $0 \%\left[\mathrm{C}_{2} \mathrm{C}_{1} \mathrm{Im}\right][\mathrm{OAc}]$ (0.52 mM ABTS) and 4\% [ $\left.\mathrm{C}_{2} \mathrm{C}_{1} \mathrm{Im}\right][\mathrm{OAc}](1.90 \mathrm{mM}$ ABTS). The different $\mathrm{K}_{\mathrm{m}}$ and $\mathrm{k}_{\mathrm{cat}}$ variations with IL concentration support the presence of two major binding sites. The first is a high affinity non-competitive binding site that lowers the enzyme activity and is almost fully occupied in $1 \%\left[\mathrm{C}_{2} \mathrm{C}_{1} \mathrm{Im}\right][\mathrm{OAc}]$. The second is a low affinity competitive binding site that likely overlaps with the substrate binding site, which lowers the substrate affinity of the enzyme.

Previous kinetics work with laccases and ILs have shown that ILs can affect both $\mathrm{K}_{\mathrm{m}}$ and $\mathrm{k}_{\mathrm{cat}}$ of several laccases. Several $\left[\mathrm{C}_{2} \mathrm{C}_{1} \mathrm{Im}\right]^{+}$ILs lowered the activity and increased the substrate affinity of $M t L$ by uncompetitive inhibition (Tavares et al., 2008). In contrast, the IL $\left[\mathrm{C}_{2} \mathrm{C}_{1} \mathrm{Im}\right][\mathrm{Cl}]$ was found to be a competitive inhibitor of the same laccase (Sun et al., 2017). The activity of $T v L$ and $M t L$ are increased by the ILs choline dihydrogen phosphate $\left([\mathrm{Ch}]\left[\mathrm{H}_{2} \mathrm{PO}_{4}\right]\right)$ and $\left[\mathrm{C}_{2} \mathrm{C}_{1} \mathrm{Im}\right]\left[\mathrm{EtSO}_{4}\right]$, respectively; enzyme kinetics suggest these ILs decrease substrate affinity (increase $\mathrm{K}_{\mathrm{m}}$ ) but increase enzyme activity (increase $\mathrm{V}_{\max }$ ) via 

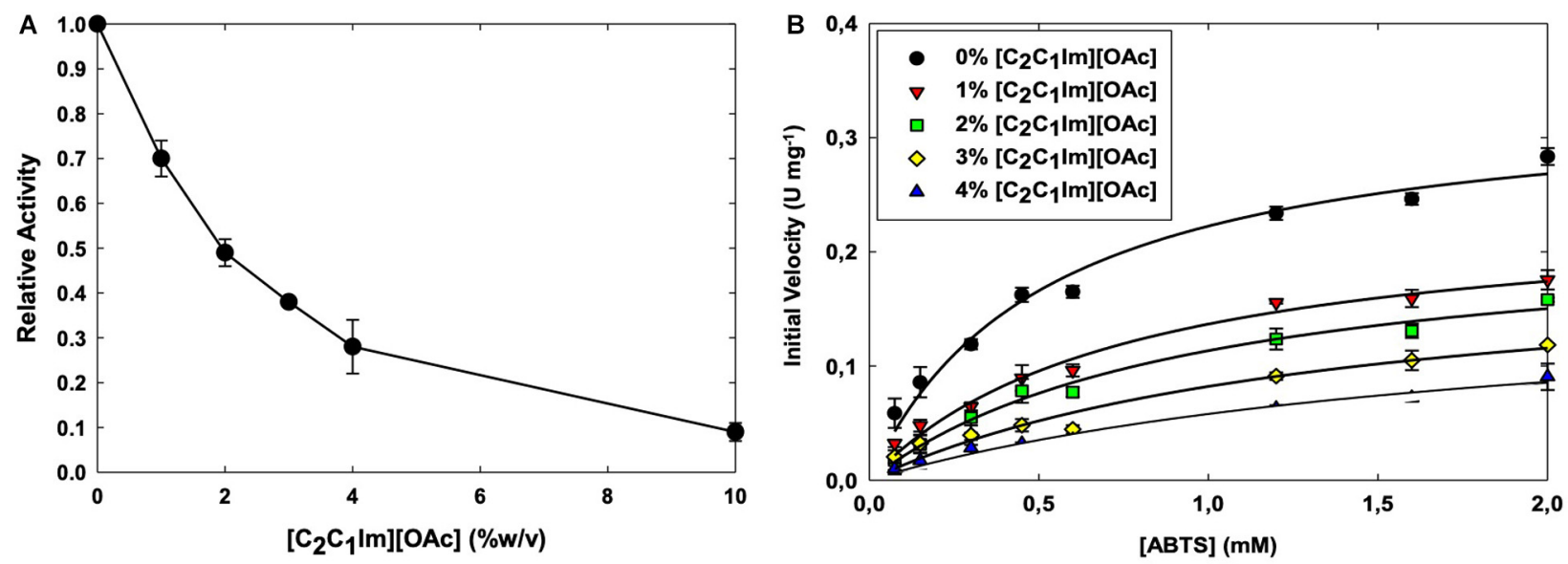

FIGURE 1 | Activity of the WT TtL in different concentrations of $\left[\mathrm{C}_{2} \mathrm{C}_{1} \mathrm{Im}\right][\mathrm{OAc}] \mathbf{( A )}$. Michaelis-Menten curves of $T t L$ in different concentrations of [ $\left.\mathrm{C}_{2} \mathrm{C}_{1} \mathrm{Im}\right][\mathrm{OAc}] \mathbf{( B )}$. Values shown are mean with error bars representing the SD of three experiments.

an uncompetitive inhibition mechanism (Fernández-Fernández et al., 2014; Galai et al., 2015).

\section{Docking Simulations}

To gain insight into the possible binding locations of $\left[\mathrm{C}_{2} \mathrm{C}_{1} \mathrm{Im}\right][\mathrm{OAc}]$ on the surface of $T t L$, we performed docking simulations with AutoDock. Figures 2A,B show the most populated IL docking poses to the surfaces of [E] and [E][S], respectively, after 1,000 docking simulations with AutoDock. Neither the cation nor the anion binds close enough to the coppers to suggest that the IL disrupts the residues that coordinate and stabilize the coppers. The binding locations of the cation and the anion to the surface of $T t L$ is affected by the presence of ABTS in the active site. The binding location of the cation to [E] (Figure 2A) appears to overlap with ABTS bound in the active site, leading to the displacement of the cation when docked to [E] [S] (Figure 2B). This suggests that the cation directly competes with the ABTS for the active site which leads to the increased $K_{m}$ seen in the enzyme kinetics. Similarly, there is a shift in the anion binding site when docked to [E] vs. [E][S]; however, the anion binding location does not overlap with the ABTS. This suggests that the anion plays a role decreasing $\mathrm{k}_{\mathrm{cat}}$ but may also contribute to the change in $\mathrm{K}_{\mathrm{m}}$, since substrate affinity would be decreased by the cost of displacing the anion.

TABLE 1 | Kinetic constants of the WT TtL in different concentrations of $\left[\mathrm{C}_{2} \mathrm{C}_{1} \operatorname{Im}\right][\mathrm{OAc}]$.

\begin{tabular}{|c|c|c|c|c|}
\hline $\begin{array}{l}{\left[C_{2} C_{1} I m\right][O A c]} \\
(\% w / v)\end{array}$ & $\begin{array}{c}\mathrm{K}_{\mathrm{m}} \\
\text { (mM ABTS) }\end{array}$ & $\begin{array}{c}\mathrm{V}_{\max } \\
\left(\mathrm{U} \mathrm{mg} \mathrm{TtL}^{-1}\right)\end{array}$ & $\begin{array}{l}\mathbf{k}_{\text {cat }} \\
\left(\mathbf{s}^{-1}\right)\end{array}$ & $\begin{array}{c}\mathrm{K}_{\mathrm{cat}} / \mathrm{K}_{\mathrm{m}} \\
\left(\mathrm{s}^{-1} \mathrm{mM}^{-1}\right)\end{array}$ \\
\hline $0 \%\left[\mathrm{C}_{2} \mathrm{C}_{1} \mathrm{Im}\right][\mathrm{OAc}]$ & $0.52 \pm 0.05$ & $0.34 \pm 0.01$ & $0.41 \pm 0.01$ & 0.78 \\
\hline $1 \%\left[\mathrm{C}_{2} \mathrm{C}_{1} \operatorname{Im}\right][\mathrm{OAc}]$ & $0.76 \pm 0.08$ & $0.24 \pm 0.01$ & $0.29 \pm 0.01$ & 0.38 \\
\hline $2 \%\left[\mathrm{C}_{2} \mathrm{C}_{1} \mathrm{Im}\right][\mathrm{OAc}]$ & $0.96 \pm 0.10$ & $0.22 \pm 0.01$ & $0.27 \pm 0.01$ & 0.28 \\
\hline $3 \%\left[\mathrm{C}_{2} \mathrm{C}_{1} \mathrm{Im}\right][\mathrm{OAc}]$ & $1.34 \pm 0.30$ & $0.20 \pm 0.02$ & $0.24 \pm 0.03$ & 0.17 \\
\hline $4 \%\left[\mathrm{C}_{2} \mathrm{C}_{1} \mathrm{Im}\right][\mathrm{OAc}]$ & $1.90 \pm 0.33$ & $0.17 \pm 0.02$ & $0.20 \pm 0.02$ & 0.11 \\
\hline
\end{tabular}

Values shown are mean \pm standard error (SE) of three experiments.
Docking results from this work are consistent with previous simulations examining docking locations of several ILs to $T v L$ and docking of alkylimidazolium cations to $M t L$. Highly populated binding sites were found close to the T1 copper when $\left[\mathrm{C}_{2} \mathrm{C}_{1} \mathrm{Im}\right][\mathrm{OAc}],[\mathrm{Ch}][\mathrm{Lys}]$, and diethylamine hydrogen sulfate ([DEA $]\left[\mathrm{HSO}_{4}\right]$ ) were docked to TvL (Stevens et al., 2019). When docked to $M t L$, short alkyl chain length cations $\left(\mathrm{C}_{2}-\mathrm{C}_{6}\right)$ diffused into the active site whereas the long chain length cations $\left(\mathrm{C}_{8}-\mathrm{C}_{10}\right)$ interacted with leucine residues around the active site (Sun et al., 2017). However, the activity of $M t L$ is increased in the presence of $\left[\mathrm{C}_{2} \mathrm{C}_{1} \mathrm{Im}\right]\left[\mathrm{EtSO}_{4}\right]$ (Fernández-Fernández et al., 2014), therefore IL docking close to the T1 copper does not imply the IL will inhibit laccase activity.

\section{Rational Design of TtL}

The mutations were chosen based on several approaches aimed at improving enzyme activity and stability in ILs. Recent directed evolution and semi-rational design studies have identified the L1 loop in $T v L$ as a key target for laccase engineering. A triple mutant targeting the alanines on the L1 loop in TvL, A310D/A312P/A318R, retained 21\% initial activity in 40\% $\left[\mathrm{C}_{2} \mathrm{C}_{1} \mathrm{Im}\right]\left[\mathrm{EtSO}_{4}\right]$, compared to $0 \%$ remaining activity for the WT laccase (Wallraf et al., 2018). The L1 loop in TtL presents 3 alanines (Ala320, Ala332, and Ala341) (Supplementary Figure S1A). The mutations of these alanines were chosen based on recent chemical modifications of enzymes in ILs. Reducing the ratio of positively charged amines to negatively charged acids on the enzyme surface by acetylation or succinylation improved their activity and stability in ILs (Erik and Kaar, 2013; Nordwald et al., 2014). For this reason, the Ala320, Ala332, and Ala341 from TtL L1 loop were mutated to: A320D/E, A332D/E, and A341D/E. Although we could have selected additional mutations based on previous studies with TvL (e.g., A320P or A332R), we chose the mutations to aspartate and glutamate in order to limit our design space. Additionally, this strategy of engineering the L1 loop is based on studies with a fungal laccase; however, we felt it appropriate to apply this strategy to the bacterial 
laccase used in this study. We also made mutations to Glu170 based on previous work improving the activity of a laccase-like enzyme from B. subtilis in ILs. The catalytic efficiency $\left(\mathrm{k}_{\mathrm{cat}} / \mathrm{K}_{\mathrm{m}}\right)$ of $B$. subtilis HR03 mutants $\mathrm{E} 188 \mathrm{~F}$ and E188Y was increased compared to the WT in several $\left[\mathrm{C}_{n} \mathrm{C}_{1} \mathrm{Im}\right][\mathrm{Cl}]$ ILs (Dabirmanesh et al., 2015). Through sequential alignment, we identified a homologous glutamate residue in TtL, Glu170 (Supplementary Figure S1B), which was mutated to both tyrosine (E170Y) and phenylalanine (E170F).

Aiming to improve the activity of $T t L$ in $\left[\mathrm{C}_{2} \mathrm{C}_{1} \mathrm{Im}\right][\mathrm{OAc}]$, we made 8 single amino acid mutations to $T t L$. With the exception of the E170Y mutant at $0 \%$ IL, none of the mutations significantly improved the activity of $T t L$ in buffer or $\left[\mathrm{C}_{2} \mathrm{C}_{1} \mathrm{Im}\right][\mathrm{OAc}]$ when compared to WT (Table 2). The A320 mutations significantly decreased the activity in buffer and some IL concentrations, as did the E170F mutation at $2 \%\left[\mathrm{C}_{2} \mathrm{C}_{1} \mathrm{Im}\right][\mathrm{OAc}]$. There were no significant differences from WT when normalizing each variant to its activity in $0 \% \mathrm{IL}$, except for the lower activity of the E170Y mutant in 2\% $\left[\mathrm{C}_{2} \mathrm{C}_{1} \mathrm{Im}\right][\mathrm{OAc}]$, indicative of its generally greater sensitivity to low $\left[\mathrm{C}_{2} \mathrm{C}_{1} \mathrm{Im}\right][\mathrm{OAc}]$ concentrations.
Despite our results showing that engineering the L1 loop of $T t L$ with single amino acid mutations does not increase activity in ILs, it is important to note that single mutations can be deleterious as it was observed for the A318V mutant of $T v L$, which decreased activity in ILs relative to WT (Haifeng et al., 2013). It is only when multiple amino acid mutations are made to the L1 loop that the laccase activity increased in ILs (Wallraf et al., 2018). Additionally, the increase in the catalytic efficiency of the HR03 mutants was attributed to increased $\pi-\pi$ and $\pi-$ anion interactions between the mutants and several aspartate and tyrosine residues present on the enzyme surface (Dabirmanesh et al., 2015). Supplementary Figure S2 shows there are relatively fewer aromatic and charged residues surrounding Glu170 in TtL that could help stabilize the E170Y/F mutants.

\section{DISCUSSION}

In this study we showed that unlike most thermophilic enzymes the activity of the hyperthermophilic, bacterial laccase
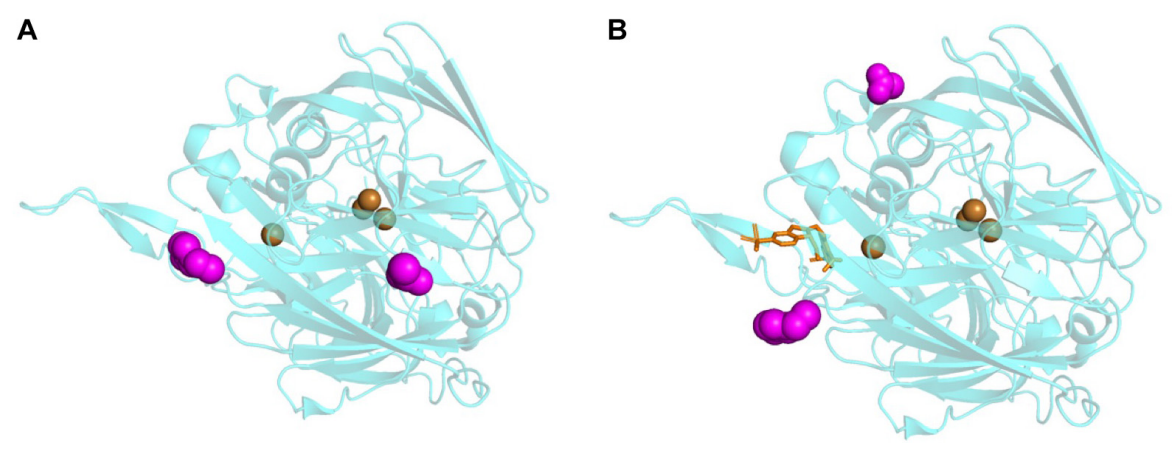

FIGURE 2 | Top docking locations from AutoDock of $\left[\mathrm{C}_{2} \mathrm{C}_{1} \mathrm{Im}\right][\mathrm{OAc}]$ to the surface of [E] (A) and [E][S] (B). The IL is shown as magenta spheres, the coppers are shown as brown spheres, and ABTS is shown as orange sticks.

TABLE 2 | Activity of WT and mutants relative to activity in buffer in different concentrations of $\left[\mathrm{C}_{2} \mathrm{C}_{1} \mathrm{Im}\right][\mathrm{OAc}]$.

\begin{tabular}{|c|c|c|c|c|c|c|c|c|c|}
\hline IL (\%w/v) & WT & A320D & A320E & A332D & A332E & A341D & A341E & E170F & E170Y \\
\hline \multicolumn{10}{|c|}{ Relative to Activity in Buffer } \\
\hline 0 & $1.00^{\mathrm{a}}$ & $1.00^{\mathrm{a}}$ & $1.00^{\mathrm{a}}$ & $1.00^{\mathrm{a}}$ & $1.00^{\mathrm{a}}$ & $1.00^{\mathrm{a}}$ & $1.00^{\mathrm{a}}$ & $1.00^{\mathrm{a}}$ & $1.00^{\mathrm{a}}$ \\
\hline 1 & $0.70 \pm 0.04^{a}$ & $0.72 \pm 0.07^{a}$ & $0.75 \pm 0.05^{a}$ & $0.70 \pm 0.03^{a}$ & $0.64 \pm 0.01^{a}$ & $0.72 \pm 0.04^{a}$ & $0.70 \pm 0.03^{a}$ & $0.71 \pm 0.01^{a}$ & $0.58 \pm 0.04^{a}$ \\
\hline 2 & $0.49 \pm 0.03^{a}$ & $0.42 \pm 0.05^{a}$ & $0.44 \pm 0.05^{a}$ & $0.45 \pm 0.02^{a}$ & $0.42 \pm 0.04^{a}$ & $0.45 \pm 0.05^{a}$ & $0.43 \pm 0.03^{a}$ & $0.39 \pm 0.02^{a}$ & $0.33 \pm 0.03^{b}$ \\
\hline 3 & $0.38 \pm 0.01^{a}$ & $0.41 \pm 0.05^{a}$ & $0.42 \pm 0.04^{a}$ & $0.40 \pm 0.03^{a}$ & $0.40 \pm 0.04^{a}$ & $0.38 \pm 0.03^{a}$ & $0.35 \pm 0.04^{a}$ & $0.37 \pm 0.04^{a}$ & $0.29 \pm 0.01^{a}$ \\
\hline 4 & $0.28 \pm 0.06^{a}$ & $0.26 \pm 0.04^{a}$ & $0.31 \pm 0.06^{a}$ & $0.32 \pm 0.01^{a}$ & $0.31 \pm 0.05^{a}$ & $0.28 \pm 0.04^{a}$ & $0.28 \pm 0.04^{a}$ & $0.32 \pm 0.05^{a}$ & $0.22 \pm 0.02^{a}$ \\
\hline 10 & $0.09 \pm 0.02^{a}$ & $0.09 \pm 0.02^{a}$ & $0.09 \pm 0.02^{a}$ & $0.09 \pm 0.00^{a}$ & $0.09 \pm 0.03^{a}$ & $0.10 \pm 0.01^{a}$ & $0.09 \pm 0.01^{a}$ & $0.09 \pm 0.02^{a}$ & $0.11 \pm 0.00^{a}$ \\
\hline \multicolumn{10}{|c|}{ Relative to WT Activity in Buffer } \\
\hline 0 & $1.00^{\mathrm{a}}$ & $0.85 \pm 0.00^{b}$ & $0.73 \pm 0.03^{b}$ & $0.96 \pm 0.01^{a}$ & $0.94 \pm 0.06^{a}$ & $1.00 \pm 0.05^{a}$ & $1.07 \pm 0.04^{a}$ & $0.94 \pm 0.04^{a}$ & $1.23 \pm 0.04^{b}$ \\
\hline 1 & $0.70 \pm 0.04^{a}$ & $0.58 \pm 0.05^{a}$ & $0.52 \pm 0.06^{b}$ & $0.67 \pm 0.02^{a}$ & $0.63 \pm 0.04^{a}$ & $0.72 \pm 0.04^{a}$ & $0.75 \pm 0.03^{a}$ & $0.68 \pm 0.05^{a}$ & $0.71 \pm 0.04^{a}$ \\
\hline 2 & $0.49 \pm 0.03^{a}$ & $0.33 \pm 0.04^{b}$ & $0.32 \pm 0.03^{b}$ & $0.43 \pm 0.02^{a}$ & $0.40 \pm 0.04^{a}$ & $0.45 \pm 0.05^{a}$ & $0.46 \pm 0.03^{a}$ & $0.37 \pm 0.02^{b}$ & $0.41 \pm 0.04^{a}$ \\
\hline 3 & $0.38 \pm 0.01^{a}$ & $0.33 \pm 0.04^{a}$ & $0.30 \pm 0.03^{a}$ & $0.38 \pm 0.03^{a}$ & $0.37 \pm 0.04^{a}$ & $0.38 \pm 0.03^{a}$ & $0.38 \pm 0.04^{a}$ & $0.35 \pm 0.04^{a}$ & $0.36 \pm 0.01^{a}$ \\
\hline 4 & $0.28 \pm 0.06^{a}$ & $0.20 \pm 0.03^{a}$ & $0.22 \pm 0.04^{a}$ & $0.28 \pm 0.04^{a}$ & $0.29 \pm 0.04^{a}$ & $0.29 \pm 0.04^{a}$ & $0.30 \pm 0.04^{a}$ & $0.30 \pm 0.05^{a}$ & $0.27 \pm 0.02^{a}$ \\
\hline 10 & $0.09 \pm 0.02^{\mathrm{a}}$ & $0.06 \pm 0.00^{\mathrm{a}}$ & $0.07 \pm 0.02^{a}$ & $0.10 \pm 0.02^{\mathrm{a}}$ & $0.09 \pm 0.03^{a}$ & $0.10 \pm 0.01^{a}$ & $0.10 \pm 0.01^{a}$ & $0.09 \pm 0.02^{\mathrm{a}}$ & $0.12 \pm 0.01^{a}$ \\
\hline
\end{tabular}

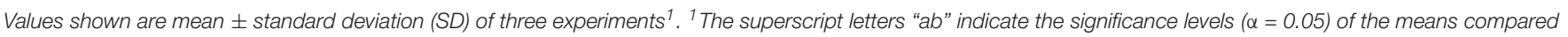
to the WT means. 
from $T$. thermophilus is sensitive to the presence of the IL $\left[\mathrm{C}_{2} \mathrm{C}_{1} \mathrm{Im}\right][\mathrm{OAc}]$. Through in vitro and in silico techniques, we provide information about (1) the inhibition of TtL by $\left[\mathrm{C}_{2} \mathrm{C}_{1} \mathrm{Im}\right][\mathrm{OAc}]$ and (2) rational design of $\mathrm{Tt} L$ to improve activity in $\left[\mathrm{C}_{2} \mathrm{C}_{1} \mathrm{Im}\right][\mathrm{OAc}]$. The biocompatibility screening showed that $>50 \%$ initial enzyme velocity is lost in just $2 \%\left[\mathrm{C}_{2} \mathrm{C}_{1} \mathrm{Im}\right][\mathrm{OAc}]$. The docking simulations, along with the enzyme kinetics results, suggest that $\left[\mathrm{C}_{2} \mathrm{C}_{1} \mathrm{Im}\right][\mathrm{OAc}]$ inhibits the activity of $T t L$ by interfering with ABTS binding to the active site (competitive inhibition) and interfering with the ABTS oxidation once it is bound (uncompetitive inhibition). We made several single amino acid mutations to $T t L$ with the aim of improving the activity in $\left[\mathrm{C}_{2} \mathrm{C}_{1} \mathrm{Im}\right][\mathrm{OAc}]$. These mutations were made based on previous studies that focused on engineering the L1 loop in fungal laccases as well as previous work that improved the activity of a bacterial laccase in ILs. While the E170Y mutant displayed significantly higher activity in buffer, none of the mutants had significantly higher levels of activity in $\left[\mathrm{C}_{2} \mathrm{C}_{1} \mathrm{Im}\right][\mathrm{OAc}]$ when compared to the WT enzyme. We have shown that thermophilicity alone does not indicate whether or not an enzyme will have high activity in ILs. Future studies might aim to better understand the mechanism underlying inhibition of $T t L$ by $\left[\mathrm{C}_{2} \mathrm{C}_{1} \mathrm{Im}\right]$ [OAc] or other ILs using molecular dynamics (MD) simulations, crystal structure determination, or mutagenesis, along with employing other techniques (e.g., multiple amino acid mutations, chemical modifications, immobilization, computational design) to improve $T t L$ activity in ILs.

\section{DATA AVAILABILITY STATEMENT}

The raw data supporting the conclusions of this article will be made available by the authors, without undue reservation.

\section{REFERENCES}

An, H., Xiao, T., Fan, H., and Wei, D. (2015). Molecular characterization of a novel thermostable laccase PPLCC2 from the brown rot fungus Postia placenta MAD-698-R. Electr. J. Biotechnol. 18, 451-458. doi: 10.1016/j.ejbt.2015.09.004

Beckham, G. T., Johnson, C. W., Karp, E. M., Salvachúa, D., and Vardon, D. R. (2016). Opportunities and challenges in biological lignin valorization. Curr. Opin. Biotechnol. 42, 40-53. doi: 10.1016/j.copbio.2016.02.030

Bhatia, S. K., Jagtap, S. S., Bedekar, A. A., Bhatia, R. K., Patel, A. K., Pant, D., et al. (2020). Recent developments in pretreatment technologies on lignocellulosic biomass: effect of key parameters, technological improvements, and challenges. Bioresour. Technol. 300:122724. doi: 10.1016/j.biortech.2019.122724

Boerjan, W., Ralph, J., and Baucher, M. (2003). Lignin biosynthesis. Annu. Rev. Plant Biol. 54, 519-546. doi: 10.1146/annurev.arplant.54.031902.134938

Brandt, A., Grasvik, J., Hallett, J. P., and Welton, T. (2013). Deconstruction of lignocellulosic biomass with ionic liquids. Green Chem. 15, 550-583. doi: 10. 1039/C2GC36364J

Brennecke, J. F., and Maginn, E. J. (2001). Ionic liquids: innovative fluids for chemical processing. AIChE J. 47, 2384-2389. doi: 10.1002/aic.690471102

Brown, M. E., and Chang, M. C. Y. (2014). Exploring bacterial lignin degradation. Curr. Opin. Chem. Biol. 19, 1-7. doi: 10.1016/j.cbpa.2013.11.015

Bugg, T. D. H., Ahmad, M., Hardiman, E. M., and Rahmanpour, R. (2011). Pathways for degradation of lignin in bacteria and fungi. Nat. Prod. Rep. 28, 1883-1896. doi: 10.1039/C1NP00042J

Cotoruelo, L. M., Marqués, M. D., Leiva, A., Rodríguez-Mirasol, J., and Cordero, T. (2011). Adsorption of oxygen-containing aromatics used in petrochemical,

\section{AUTHOR CONTRIBUTIONS}

JCS, DR, CD, and JS conceptualized the work, designed the experiments, and analyzed the data. JCS conducted the experiments and wrote the manuscript. All authors have approved the manuscript and agreed with submission to Frontiers in Energy Research.

\section{FUNDING}

The authors acknowledge the support from the National Science Foundation under Cooperative Agreement Nos. 1355438 and 1632854 and the National Institute of Food and Agriculture, United States Department of Agriculture, Hatch-Multistate project under accession number 1018315. This material is based upon research supported by the Chateaubriand Fellowship of the Office for Science \& Technology of the Embassy of France in the United States.

\section{ACKNOWLEDGMENTS}

The authors would like to thank Dr. Isabelle André and Dr. Jérémy Esque (Toulouse Biotechnology Institute) for guidance on the molecular docking simulations.

\section{SUPPLEMENTARY MATERIAL}

The Supplementary Material for this article can be found online at: https://www.frontiersin.org/articles/10.3389/fenrg. 2020.00158/full\#supplementary-material

pharmaceutical and food industries by means of lignin based active carbons. Adsorption 17, 539-550. doi: 10.1007/s10450-010-9319-x

Dabirmanesh, B., Khajeh, K., Ghazi, F., Ranjbar, B., and Etezad, S.-M. (2015). A semi-rational approach to obtain an ionic liquid tolerant bacterial laccase through $\pi$-type interactions. Int. J. Biol. Macromol. 79, 822-829. doi: 10.1016/ j.ijbiomac.2015.06.002

d'Acunzo, F., Galli, C., Gentili, P., and Sergi, F. (2006). Mechanistic and steric issues in the oxidation of phenolic and non-phenolic compounds by laccase or laccasemediator systems. The case of bifunctional substrates. N. J. Chem. 30, 583-591. doi: 10.1039/B516719A

Datta, S., Holmes, B., Park, J. I., Chen, Z., Dibble, D. C., Hadi, M., et al. (2010). Ionic liquid tolerant hyperthermophilic cellulases for biomass pretreatment and hydrolysis. Green Chem. 12, 338-345. doi: 10.1039/B916564A

De Wild, P. J., Huijgen, W. J. J., and Gosselink, R. J. A. (2014). Lignin pyrolysis for profitable lignocellulosic biorefineries. Biofuels Bioproducts Biorefining 8, 645-657. doi: 10.1002/bbb.1474

Doherty, W. O. S., Mousavioun, P., and Fellows, C. M. (2011). Value-adding to cellulosic ethanol: lignin polymers. Indus. Crops Products 33, 259-276. doi: 10.1016/j.indcrop.2010.10.022

Domínguez, A., Rodríguez, O., Tavares, A. P. M., Macedo, E. A., Asunción Longo, M., and Ángeles Sanromán, M. (2011). Studies of laccase from Trametes versicolor in aqueous solutions of several methylimidazolium ionic liquids. Bioresour. Technol. 102, 7494-7499. doi: 10.1016/j.biortech.2011. 05.063

Erik, M. N., and Kaar, J. L. (2013). Stabilization of Enzymes in Ionic Liquids Via Modification of Enzyme Charge. Biotechnol. Bioeng. 110:9. 
Fernández-Fernández, M., Moldes, D., Domínguez, A., Sanromán, M. Á, Tavares, A. P. M., Rodríguez, O., et al. (2014). Stability and kinetic behavior of immobilized laccase from Myceliophthora thermophila in the presence of the ionic liquid 1-ethyl-3-methylimidazolium ethylsulfate. Biotechnol. Prog. 30, 790-796. doi: 10.1002/btpr.1910

Fort, D. A., Remsing, R. C., Swatloski, R. P., Moyna, P., Moyna, G., and Rogers, R. D. (2007). Can ionic liquids dissolve wood? Processing and analysis of lignocellulosic materials with 1-n-butyl-3-methylimidazolium chloride. Green Chem. 9, 63-69. doi: 10.1039/B607614A

Galai, S., de los Rios, A., Hernandez-Fernandez, F. J., Haj Kacem, S., and TomasAlonso, F. (2015). Over-activity and stability of laccase using ionic liquids: screening and application in dye decolorization. RSC Adv. 5, 16173-16189. doi: 10.1039/C4RA07351G

Gamelas, J. A. F., Tavares, A. P. M., Evtuguin, D. V., and Xavier, A. M. B. (2005). Oxygen bleaching of kraft pulp with polyoxometalates and laccase applying a novel multi-stage process. J. Mol. Catalysis B 33, 57-64. doi: 10.1016/j.molcatb. 2005.03.001

George, A., Brandt, A., Tran, K., Zahari, S. M. N. S., Klein-Marcuschamer, D., Sun, N., et al. (2015). Design of low-cost ionic liquids for lignocellulosic biomass pretreatment. Green Chem. 17, 1728-1734. doi: 10.1039/c4gc01208a

Glenn, J. K., Morgan, M. A., Mayfield, M. B., Kuwahara, M., and Gold, M. H. (1983). An extracellular H2O2-requiring enzyme preparation involved in lignin biodegradation by the white rot basidiomycete Phanerochaete chrysosporium. Biochem. Biophys. Res. Commun. 114, 1077-1083. doi: 10.1016/0006-291X(83) 90672-1

Gschwend, F. J. V., Malaret, F., Shinde, S., Brandt-Talbot, A., and Hallett, J. P. (2018). Rapid pretreatment of Miscanthus using the low-cost ionic liquid triethylammonium hydrogen sulfate at elevated temperatures. Green Chem. 20, 3486-3498. doi: 10.1039/C8GC00837J

Gutowski, K. E., Broker, G. A., Willauer, H. D., Huddleston, J. G., Swatloski, R. P., Holbrey, J. D., et al. (2003). Controlling the Aqueous Miscibility of Ionic Liquids: Aqueous Biphasic Systems of Water-Miscible Ionic Liquids and WaterStructuring Salts for Recycle, Metathesis, and Separations. J. Am. Chem. Soc. 125, 6632-6633. doi: 10.1021/ja0351802

Haifeng, L., Zhu, L., Marco, B., Nora, C., Antje, C. S., and Schwaneberg, U. (2013). Directed laccase evolution for improved ionic liquid resistance. Green Chem. $15: 8$.

Hullo, M.-F., Moszer, I., Danchin, A., and Martin-Verstraete, I. (2001). CotA of Bacillus subtilis Is a Copper-Dependent Laccase. J. Bacteriol. 183, 5426-5430. doi: 10.1128/jb.183.18.5426-5430.2001

Kiiskinen, L.-L., Kruus, K., Bailey, M., Ylösmäki, E., Siika-aho, M., and Saloheimo, M. (2004). Expression of Melanocarpus albomyces laccase in Trichoderma reesei and characterization of the purified enzyme. Microbiology 150, 30653074. doi: 10.1099/mic.0.27147-0

Kilpeläinen, I., Xie, H., King, A., Granstrom, M., Heikkinen, S., and Argyropoulos, D. S. (2007). Dissolution of Wood in Ionic Liquids. J. Agric. Food Chem. 55, 9142-9148. doi: 10.1021/jf071692e

Kleinert, M., and Barth, T. (2008). Towards a lignincellulosic biorefinery: direct one-step conversion of lignin to hydrogen-enriched biofuel. Energy Fuels 22, 1371-1379. doi: 10.1021/ef700631w

Klibanov, A. M. (2001). Improving enzymes by using them in organic solvents. Nature 409, 241-246. doi: 10.1038/35051719

Laskar, D. D., Yang, B., Wang, H., and Lee, J. (2013). Pathways for biomassderived lignin to hydrocarbon fuels. Biofuels Bioproducts Biorefining 7, 602-626. doi: 10.1002/bbb.1422

Linger, J. G., Vardon, D. R., Guarnieri, M. T., Karp, E. M., Hunsinger, G. B., Franden, M. A., et al. (2014). Lignin valorization through integrated biological funneling and chemical catalysis. Proc. Natl. Acad. Sci. U.S.A. 111, 12013-12018. doi: 10.1073/pnas.1410657111

Liu, H., Zhu, L., Bocola, M., Chen, N., Spiess, A. C., and Schwaneberg, U. (2013). Directed laccase evolution for improved ionic liquid resistance. Green Chem. 15, 1348-1355. doi: 10.1039/C3GC36899H

Liu, X., Gillespie, M., Ozel, A. D., Dikici, E., Daunert, S., and Bachas, L. G. (2011). Electrochemical properties and temperature dependence of a recombinant laccase from Thermus thermophilus. Anal. Bioanal. Chem. 399, 361-366. doi: 10.1007/s00216-010-4345-9

Miyazaki, K. (2005). A hyperthermophilic laccase from Thermus thermophilus HB27. Extremophiles 9, 415-425. doi: 10.1007/s00792-005-0458- z
Mottiar, Y., Vanholme, R., Boerjan, W., Ralph, J., and Mansfield, S. D. (2016). Designer lignins: harnessing the plasticity of lignification. Curr. Opin. Biotechnol. 37(Suppl. C), 190-200. doi: 10.1016/j.copbio.2015.10.009

Mozhaev, V. V., Khmelnitsky, Y. L., Sergeeva, M. V., Belova, A. B., Klyachko, N. L., Levashov, A. V., et al. (1989). Catalytic activity and denaturation of enzymes in water/organic cosolvent mixtures. Eur. J. Biochem. 184, 597-602. doi: 10.1111/j.1432-1033.1989.tb15055.x

Munk, L., Sitarz, A. K., Kalyani, D. C., Mikkelsen, J. D., and Meyer, A. S. (2015). Can laccases catalyze bond cleavage in lignin? Biotechnol. Adv. 33, 13-24. doi: 10.1016/j.biotechadv.2014.12.008

National Research Council, National Academy of Engineering, National Academy of Sciences, and America's Energy Future Panel on Alternative Liquid Transportation Fuels (2009). Liquid Transportation Fuels from Coal and Biomass: Technological Status, Costs, and Environmental Impacts. Washington, DC: The National Academies Press.

Nordwald, E. M., Brunecky, R., Himmel, M. E., Beckham, G. T., and Kaar, J. L. (2014). Charge engineering of cellulases improves ionic liquid tolerance and reduces lignin inhibition. Biotechnol. Bioeng. 111, 1541-1549. doi: 10.1002/bit. 25216

Park, S., and Kazlauskas, R. J. (2003). Biocatalysis in ionic liquids - advantages beyond green technology. Curr. Opin. Biotechnol. 14, 432-437. doi: 10.1016/ S0958-1669(03)00100-9

Patel, R., Kumari, M., and Khan, A. B. (2014). Recent advances in the applications of ionic liquids in protein stability and activity: a review. Appl. Biochem. Biotechnol. 172, 3701-3720. doi: 10.1007/s12010-014-0813-816

Piontek, K., Antorini, M., and Choinowski, T. (2002). Crystal Structure of a Laccase from the FungusTrametes versicolor at $1.90-\AA$ Resolution Containing a Full Complement of Coppers. J. Biol. Chem. 277, 37663-37669. doi: 10.1074/jbc. M204571200

Ragauskas, A. J., Beckham, G. T., Biddy, M. J., Chandra, R., Chen, F., Davis, M. F., et al. (2014). Lignin valorization: improving lignin processing in the biorefinery. Science 344:1246843 doi: 10.1126/science. 1246843

Rico, A., Rencoret, J., del Río, J. C., Martínez, A. T., and Gutiérrez, A. (2014). Pretreatment with laccase and a phenolic mediator degrades lignin and enhances saccharification of Eucalyptus feedstock. Biotechnol. Biofuels 7:6. doi: 10.1186/1754-6834-7-6

Rogers, R. D., and Seddon, K. R. (2003). Ionic Liquids-Solvents of the Future? Science 302, 792-793. doi: 10.1126/science.1090313

Semba, Y., Ishida, M., Yokobori, S.-I., and Yamagishi, A. (2015). Ancestral amino acid substitution improves the thermal stability of recombinant lignin-peroxidase from white-rot fungi, Phanerochaete chrysosporium strain UAMH 3641. Protein Eng. Design Select. 28, 221-230. doi: 10.1093/protein/ gzv023

Sette, M., Wechselberger, R., and Crestini, C. (2011). Elucidation of Lignin Structure by Quantitative 2D NMR. Chem. A Eur. J. 17, 9529-9535. doi: 10. 1002/chem.201003045

Shi, J., Balamurugan, K., Parthasarathi, R., Sathitsuksanoh, N., Zhang, S., Stavila, V., et al. (2014). Understanding the role of water during ionic liquid pretreatment of lignocellulose: co-solvent or anti-solvent? Green Chem. 16, 3830-3840. doi: 10.1039/C4GC00373J

Shi, J., Sharma-Shivappa, R. R., and Chinn, M. S. (2012). Interactions between fungal growth, substrate utilization and enzyme production during shallow stationary cultivation of Phanerochaete chrysosporium on cotton stalks. Enzyme Microb. Technol. 51, 1-8. doi: 10.1016/j.enzmictec.2012. 03.006

Singh Arora, D., and Kumar Sharma, R. (2010). Ligninolytic Fungal Laccases and Their Biotechnological Applications. Appl. Biochem. Biotechnol. 160, 17601788. doi: 10.1007/s12010-009-8676-y

Stevens, J. C., Das, L., Mobley, J. K., Asare, S. O., Lynn, B. C., Rodgers, D. W., et al. (2019). Understanding laccase-ionic liquid interactions toward biocatalytic lignin conversion in aqueous ionic liquids. ACS Sustain. Chem. Eng. 7, 1592815938. doi: 10.1021/acssuschemeng.9b02151

Suhas, C. P. J. M., and Ribeiro Carrott, M. M. L. (2007). Lignin - from natural adsorbent to activated carbon: a review. Bioresour. Technol. 98, 2301-2312. doi: 10.1016/j.biortech.2006.08.008

Sun, J., Liu, H., Yang, W., Chen, S., and Fu, S. (2017). Molecular mechanisms underlying inhibitory binding of alkylimidazolium ionic liquids to Laccase. Molecules 22:1353. doi: 10.3390/molecules22081353 
Tavares, A. P. M., Rodriguez, O., and Macedo, E. A. (2008). Ionic liquids as alternative co-solvents for laccase: study of enzyme activity and stability. Biotechnol. Bioeng. 101:7.

Tilman, D., Socolow, R., Foley, J. A., Hill, J., Larson, E., Lynd, L., et al. (2009). Beneficial biofuels - the food, energy, and environment trilemma. Science 325, 270-271. doi: 10.1126/science.1177970

Vanholme, R., Demedts, B., Morreel, K., Ralph, J., and Boerjan, W. (2010). Lignin biosynthesis and structure. Plant Physiol. 153, 895-905. doi: 10.1104/pp.110. 155119

Varmana, A. M., Heb, L., Follenfanta, R., Wua, W., Wemmera, S., Wrobela, S. A., et al. (2016). Decoding how a soil bacterium extracts building blocks and metabolic energy from ligninolysis provides road map for lignin valorization. Proc. Natl. Acad. Sci. 113, E5802-E5811.

Verdia, P., Brandt, A., Hallett, J. P., Ray, M. J., and Welton, T. (2014). Fractionation of lignocellulosic biomass with the ionic liquid 1-butylimidazolium hydrogen sulfate. Green Chem. 16, 1617-1627. doi: 10.1039/C3GC41742E

Wallraf, A.-M., Liu, H., Zhu, L., Khalfallah, G., Simons, C., Alibiglou, H., et al. (2018). A loop engineering strategy improves laccase lcc2 activity in ionic liquid and aqueous solution. Green Chem. 20, 2801-2812. doi: 10.1039/C7GC03776G
Weng, J.-K., and Chapple, C. (2010). The origin and evolution of lignin biosynthesis. N. Phytol. 187, 273-285. doi: 10.1111/j.1469-8137.2010.03327.x

Yoshida, H. (1883). LXIII.-Chemistry of lacquer (Urushi). Part I. Communication from the Chemical Society of Tokio. J. Chem. Soc. Trans. 43, 472-486. doi: 10.1039/CT8834300472

Zeng, J., Helms, G. L., Gao, X., and Chen, S. (2013). Quantification of Wheat Straw Lignin Structure by Comprehensive NMR Analysis. J. Agric. Food Chem. 61, 10848-10857. doi: 10.1021/jf4030486

Conflict of Interest: The authors declare that the research was conducted in the absence of any commercial or financial relationships that could be construed as a potential conflict of interest.

Copyright (c) 2020 Stevens, Rodgers, Dumon and Shi. This is an open-access article distributed under the terms of the Creative Commons Attribution License (CC BY). The use, distribution or reproduction in other forums is permitted, provided the original author(s) and the copyright owner(s) are credited and that the original publication in this journal is cited, in accordance with accepted academic practice. No use, distribution or reproduction is permitted which does not comply with these terms. 